Pesq. Vet. Bras. 36(Supl.1):79-88, junho 2016 DOI: $10.1590 / \mathrm{S} 0100-736 \mathrm{X} 2016001300012$

\title{
Potential for in vitro mesoderm differentiation of Wharton's jelly cells from ovine umbilical cord isolated in different culture media ${ }^{1}$
}

\author{
Ronaldo P. Dias ${ }^{2 *}$, Maria F.S. Teixeira ${ }^{2,3}$, Edmara C. Costa ${ }^{4}$, Anderson C. Farias ${ }^{2}$, \\ Dalva A.A. Azevedo ${ }^{2}$, Tereza D.F. Aguiar ${ }^{2}$ and Mariana A. Pinheiro ${ }^{5}$
}

\begin{abstract}
Dias R.P., Teixeira M.F.S., Costa E.C., Farias A.C., Azevedo D.A.A., Aguiar T.D.F. \& Pinheiro M.A. 2016. Potential for in vitro mesoderm differentiation of Wharton's jelly cells from ovine umbilical cord isolated in different culture media. Pesquisa Veterinária Brasileira 36(Supl.1):79-88. Programa de Pós-Graduação em Ciências Veterinárias, Laboratório de Virologia, Faculdade de Veterinária, Universidade Estadual do Ceará, Av. Silas Munguba, 1700, Itaperi, Fortaleza, CE 60740-000, Brasil. E-mail: ronaldodias01@yahoo.com.br

The mammalian Wharton's jelly of umbilical cord (WJUC) is a promising source of multipotent cells, providing advantages due to ethical implications, ease of collection and the absence of teratomas in pre-clinical trials. Ovine multipotent cells have already been isolated from various tissues, however there are no reports using umbilical cords in this species. This study aimed to investigate the best medium to transport the umbilical cord, to isolate and maintain ovine WJUC cells and to compare in vitro growth and mesodermal differentiation potential. Eight ovine umbilical cords were obtained during parturition, sectioned and transported in six different media: MEM, low glucose DMEM, M199, RPMI 1640, PBS and saline. For each transportation medium, four culture media were used and the tissue was explanted in 24-well plates and cultured in MEM, low glucose DMEM, M199 and RPMI 1640, all with 10\% FBS. Every experiment was conducted with low-passage (P2), investigating MTT viability during four days and adipogenic, chondrogenic and osteogenesis differentiation was induced in vitro. The most effective transport medium $(p<0.1)$ was low glucose DMEM. There was no bacterial or fungal contamination from collection. Cells from Wharton's jelly of ovine umbilical cords collected at natural birth possess fibroblastic morphology and the capacity for in vitro differentiation into adipogenic, chondrogenic and osteogenic cell lines. MTT tests and in vitro differentiation experiments revealed that cell culture medium modulates the behavior of cells and is an important factor for proliferation and maintenance of multipotency. Low glucose DMEM was the most suitable medium for the isolation of cells from Wharton's jelly of ovine umbilical cord.
\end{abstract}

INDEX TERMS: Sheep umbilical cord matrix, multipotent cells, adipogenesis, chondrogenesis, osteogenesis.

\footnotetext{
${ }^{1}$ Received on November 14, 2015.

Accepted for publication on April 11, 2016.

${ }^{2}$ Programa de Pós-Graduação em Ciências Veterinárias, Laboratório de Virologia, Faculdade de Veterinária, Universidade Estadual do Ceará (UECE), Avenida Silas Munguba 1700, Itaperi, Fortaleza, CE 60740-000, Brazil. Pesquisa de doutorado com apoio da CAPES. *Corresponding author: ronaldodias01@yahoo.com.br

${ }^{3}$ Bolsista de Produtividade em Pesquisa do CNPq.

${ }^{4}$ Universidade da Integração Internacional da Lusofonia Afro-Brasileira, Avenida da Abolição 3, Centro, Redenção, CE 62790-000, Brazil.

${ }^{5}$ Bolsista de Iniciação Científica, Fundação Cearense de Apoio ao Desenvolvimento Científico e Tecnológico (Funcap), Faculdade de Veterinária, UECE, Av. Silas Munguba 1700, Itaperi, Fortaleza, CE 60740-000.
}

RESUMO.- [Potencial de diferenciação in vitro de células provenientes da geleia de Wharton de cordões umbilicais ovinos isolados em diferentes meios de cultivo.] A geleia de Wharton do cordão umbilical (GWCU) de mamíferos é uma fonte promissora de células multipotentes, sendo vantajosa por aspectos éticos, facilidade de coleta e não causar teratomas em ensaios pré-clínicos. Em ovinos, células multipotentes já foram isoladas de vários tecidos, no entanto, não existem relatos do isolamento a partir do cordão umbilical nesta espécie. 0 objetivo do presente estudo foi investigar o melhor meio para o transporte do cordão umbilical, isolar e manter as células da GWCU 
ovino em diferentes meios e comparar a proliferação e o potencial de diferenciação mesodermal in vitro. Oito cordões umbilicais foram obtidos, por ocasião do parto natural, seccionados e transportados em seis diferentes meios que consistiram em MEM, DMEM baixa glicose, M199, RPMI 1640, PBS e soro fisiológico. Para cada meio de transporte foram utilizados quatro meios de cultivo, sendo o tecido explantado em placas de 24 poços e cultivados em MEM, DMEM baixa glicose, M199 e RPMI 1640, todos com 10\% SFB. Todo o experimento foi realizado em baixa passagem (P2) investigando viabilidade pelo MTT por quatro dias além da indução à diferenciação adipogênica, condrogênica e osteogênica in vitro. 0 meio de transporte mais efetivo $(P<0,10)$ foi o DMEM baixa glicose. Não houve contaminações bacterianas ou fúngicas decorrentes da coleta. Células oriundas da geleia de Wharton do cordão umbilical ovino colhido por ocasião do parto natural possuem morfologia fibroblastóide e capacidade de diferenciação in vitro nas linhagens adipogênica, condrogênica e osteogênica. Os ensaios de MTT e diferenciação in vitro, revelaram que o meio de cultura celular modula o comportamento destas células, sendo um fator importante tanto para a proliferação como para a manutenção da multipotência, destacando o DMEM baixa glicose como o meio mais adequado para o transporte e isolamento de células da geleia de Wharton do cordão umbilical ovino.

TERMOS DE INDEXAC̄̃O: Matriz do cordão umbilical ovino, células multipotentes, adipogênese, condrogênese, osteogênese.

\section{INTRODUCTION}

In recent years, fetal membranes such as the placenta, placental membranes, umbilical cord, and amniotic fluid have been recognized as an unexplored resource for the field of regenerative medicine. These tissues have been shown to be a rich source of cells with elevated multipotency and potent immunosuppressive properties that demonstrate how these cells are exciting promising new tool for the treatment of diseases (Murphy \& Atala 2013). In addition, the absence of ethical conflicts implied in collection and of teratogenic effects involved in the application are considerable advantages when compared to embryogenic stem cells and pluripotent-induced cells (Condic \& Rao 2010).

Fetal membranes are a rich, non-invasive and easy to collect source of these cells, which present great capacity to proliferate and differentiate (De Vita et al. 2012). Umbilical cord is one example of tissue with promising results in research to provide new tools to treating several diseases. This fetal membrane is covered by amniotic epithelium that protects a gelatinous and elastic matrix composed by mucopolysaccharides (hyaluronic acid and chondroitin sulfate) referred as Wharton's jelly (WJ), named after Thomas Wharton in 1856 (Forraz \& McGuckin 2010).

Umbilical cord is routinely discarded after parturition and cell isolation is facilitated due to the location outside the fetal body. This excludes the necessity of invasive collection procedures, which often occurs when adult cells are isolated from other sources, possibly causing discomfort and risk to patients. Furthermore, the relatively large vo- lume of umbilical cord and easy manipulation theoretically enhances the number of cells that may be extracted. This favors a substantial number of cells in several passages, avoiding long culture procedures and extended ex vivo expansion (Iacono et al. 2015), which becomes a viable solution for obtaining cells to veterinary practice.

The ability of multipotent cells to differentiate into a variety of connective tissue cell types has rendered them an ideal candidate cell source for clinical tissue regeneration strategies (Baksh et al. 2004). WJ cells are immuno-privileged, immunosuppressive, have a multipotent differentiation capacity and are readily available as a cell source (Taghizadeh et al. 2011). In addition, the capacity of human cells derived from Wharton's jelly to proliferate and differentiate have been demonstrated and are similar to bone marrow cells (Baksh et al. 2007).

In humans, a simple method for obtaining cells from Wharton's jelly of umbilical cord (WJUC) have been described without enzymatic digestion, but simply culturing the tissue explants (Hendijani et al. 2014). With goats, the beneficial effect of cells from WJUC in cutaneous cicatrization have already been demonstrated (Azari et al. 2011). In another study, caprine cells from WJUC also enhanced the healing potential through xenotransplant in cutaneous wounds of rabbits, demonstrating improvement in the formation of epithelium and collagen with vascularization (Pratheesh et al. 2014).

With sheep, cells isolated from different sources have demonstrated in vitro capacity to differentiate into osteoblasts, adipocytes and chondrocytes, such as periodontal ligament (Gronthos et al. 2006), bone marrow (Mccarty et al, 2009), adipose tissue, umbilical cord blood (Fadel et al, 2011), peripheral blood (Lyahyai et al. 2012), amniotic liquid (Colosimo et al. 2013) and dermal skin (Jahroomishirazi et al. 2015). However, there are no studies reporting the isolation and in vitro mesoderm differentiation of cells from Wharton's jelly of ovine umbilical cord.

Sheep are an ideal model for studies in bone tissue engineering (Guo et al. 2004), and have also been proposed as an animal model for several applications in biomedical research with illnesses such as respiratory diseases (Scheerlinck 2008), cardiomyopathies (Psaltis et al. 2010, Sill et al. 2011) and neurological disorders (Fauza et al. 2008). In addition, the use of these animals in orthopedic investigations have improved due to their similarities with humans in weight, size, common structures and regenerative bone/ cartilage processes, leading to a potential in regenerative processes that have also been studied.

An important factor that must be considered in the culture of primary cells is the medium used. Studies have shown that it interferes in the differentiation potential of isolated cells (Wu et al. 2009, Lima et al. 2012, Ribeiro et al. 2013). In order to achieve success in tissues or organs engineering, it is imperative to provide a culture microenvironment to the cells that supports their proliferation and maintains their differentiation capacity.

Therefore, this study aimed to isolate ovine WJUC cells obtained during birth, to determine the best transport conditions for this tissue, to assess growth and morphologic 
aspects in different culture media and their influence in the capacity for in vitro mesoderm differentiation.

\section{MATERIALS AND METHODS}

Collection and transportation of sheep umbilical cords. Ovine umbilical cords $(\mathrm{n}=8)$ were collected during parturition of healthy mixed breed sheep from two farms located in Guaiuba city territory, in Ceará State. Before rupture, each umbilical cord was pinched with sterile hemostatic scissors and cut in a section of 6 to $10 \mathrm{~cm}$. Then, the entire fragment was washed with sterile PBS added $2 \%$ of penicillin-streptomycin (P/S) (Gibco ${ }^{\mathrm{TM}}$, Cat № 15140$122,10,000 \mathrm{U} / \mathrm{ml}$ ) for disinfection and blood removal. Each cord was immediately sectioned on a sterile petri dish in six fragments of $1 \mathrm{~cm}^{2}$, which were then placed in falcon tubes (TPP, Cat №. 91015), each containing a different transport solution. Media used for transportation were: MEM (Gibco ${ }^{\mathrm{TM}}$, Cat №. 61100-061), low glucose DMEM (Gibco ${ }^{\text {TM }}$, Cat № 31600-034), Medium 199 (M199) (Gibco $^{\mathrm{TM}}$, Cat № 11150-067), RPMI 1640 (Gibco ${ }^{\mathrm{TM}}$, Cat №. 31800022), phosphate buffered saline (PBS) and saline $0.9 \%$ (S); to all of which $4 \% \mathrm{P} / \mathrm{S}$ and $1 \%$ amphotericin $\mathrm{B}$ were added. Tubes were placed in isothermal box containing recyclable ice $\left(4^{\circ} \mathrm{C}\right)$ and sent to laboratory of Virology from State University of Ceará for the remaining procedure. This experiment was performed according to the current law and ethical principles for animal experimentation approved by the Ethics Committee for the Use of Animals of the State University of Ceará protocol number 12776979-0.

Transport media selection. In a 24-well plate (Kasvi, Cat. K12-024), fibroblast development was assessed in each cord fragment transported in each of the six different media. Every fragment from each cord originated explants, which were submitted to culture with four different cellular culture media, displaced in simple arrange $\left(A_{6 \times 4}\right)$. Culture media used were: MEM, low glucose DMEM, M199 and RPMI 1640, and to all of these $10 \%$ fetal bovine serum (FBS) (Gibco ${ }^{\mathrm{TM}}$, Cat № 10270-098), 2\% P/S and 1\% amphotericin $\mathrm{B}$ were added. In each well, three explants were placed, cultivated for 30 minutes for plate adherence in incubator at $37^{\circ} \mathrm{C}$ with humid atmosphere and $5 \% \mathrm{CO}_{2}$, then $0.5 \mathrm{~mL}$ of culture medium was added. Plates were observed daily in inverted microscope for fibroblast visualization around the explants. At day four, when the first cells were observed, scores were attributed according to the presence and quantity of fibroblasts around the explants: zero cells (score 0 ), one to five cells (score 1), six to twenty cells (score 2) and uncountable number of cells (score 3). Results were then compared and the best transport medium for cord tissue was selected.

Cord cell culture in different media. After confluence, cells were trypsinized in 24-well plates (Kasvi, Cat. K12-024) and expanded in culture flasks of $25 \mathrm{~cm}^{2}$ (Kasvi, Cat. K11-2050), each containing one culture medium, MEM, low glucose DMEM, M199 or RPMI 1640 , added $10 \%$ FBS, $2 \% \mathrm{P} / \mathrm{S}$ and $1 \%$ amphotericin $\mathrm{B}$ during the entire experiment. Cell counting in all experiments with plates was performed with Neubauer chambers.

MTT assay for cell viability evaluation (Thiazolyl Blue Tetrazolium Bromide). Growth of second passage (P2) ovine umbilical cord cells was assessed with a method that measures the activity of mitochondrial dehydrogenase enzyme, which when active is capable of metabolizing the MTT reagent resulting in a colored compound named formazan. Therefore, $100 \mu \mathrm{L}$ aliquots of cell suspension in culture medium (MEM, low glucose DMEM, M199 or RPMI 1640) added 10\% FBS, 2\% P/S and 1\% amphotericin $\mathrm{B}$, in a concentration of $1 \times 10^{5}$ cells/mL were placed in 96 well microplates (Kasvi, Cat. K12-096). For each culture medium, four repetitions in triplicate were used, resulting in 12-wells/ day. After every $24 \mathrm{~h}$ of incubation, the culture medium in the well was replaced by $100 \mu \mathrm{L}$ of the same medium added MTT (Sigma, Cat. M2003) in a $0.5 \mathrm{mg} / \mathrm{mL}$ concentration. Microplates were incubated for $4 \mathrm{~h}$ at $37^{\circ} \mathrm{C}$ to allow MTT permeation and formation of formazan crystals. Then, media containing MTT were removed and formazan crystals were solubilized with $100 \mu \mathrm{L}$ of DMSO under stirring for 5 minutes. Spectrophotometry analysis was performed with microplate reader (Metertech model $\sum 960$ ) with an absorbance of $600 \mathrm{~nm}$. Readings were performed with 24, 48, 72 and 96 hours of culture.

Differentiation in mesoderm cell line. Wharton's jelly cells cultured in second passage in four distinct media were used to identify their potential for in vitro differentiation into osteocytes, adipocytes and chondrocytes.

Osteogenic differentiation. Osteogenesis was performed using a differentiation kit (StemPro Osteogenesis Kit, Gibco, Cat. № A10072-01). Cells were trypsinized and placed in 24-well plates (Kasvi, Cat. K12-024) in a $5 \times 10^{3}$ cells $/ \mathrm{cm}^{2}$ density with culture medium added $10 \%$ FBS, antibiotics and antifungal, all incubated in humid atmosphere with $5 \% \mathrm{CO}_{2}$ at $37^{\circ} \mathrm{C}$.

After 24 hours, each medium was replaced by the osteogenesis-inducing medium in the wells of the differentiation experiment, while control wells remained with maintenance media MEM, low glucose DMEM, M199 and RPMI 1640. Differentiation as well as maintenance media were replaced every two to three days. After 21 days, cells were fixated in $4 \%$ buffered formalin for 30 minutes and then washed with distilled water. Alizarin Red S $2 \%$ solution ( $\mathrm{pH} 4.2$ ) (Sigma-Aldrich, Cat. A5533) was added to each well for three minutes and then three washings were performed with distilled water.

Adipogenic differentiation. Adipogenesis was performed using a differentiation kit (StemPro Adipogenesis Kit, Gibco, Cat. № A10070-01). Cells were trypsinized and placed in 24-well plates (Kasvi, Cat. K12-024) in a $1 \times 10^{4}$ cells $/ \mathrm{cm}^{2}$ density in culture media added $10 \% \mathrm{FBS}$, antibiotics and antifungal in humid atmosphere with $5 \% \mathrm{CO}_{2}$ at $37^{\circ} \mathrm{C}$.

After 24 hours, media were replaced by adipogenesis-inducing medium in the wells of the differentiation experiment, while control remained with maintenance media. Differentiation and maintenance media were replaced every two to three days.

After 14 days, cells were fixated with $10 \%$ buffered formalin for 10 minutes, followed by two washings with PBS. Oil Red 0 solution (Sigma, Cat. 01391) was added to the cells for 15 minutes and then washed twice with distilled water. Counter coloration was performed with Mayer's hematoxylin (Sigma, Cat. MHS16) for three minutes.

Chondrogenic differentiation. Chondrogenesis was induced using micromass technique in 24-well plates (Kasvi, Cat. K12-024) with a chondrogenesis-inducing kit (StemPro Chondrogenesis Kit, Gibco, Cat № A10071-01). Cells were trypsinized and a suspension of $1,6 \times 10^{7}$ cells $/ \mathrm{mL}$ was prepared. Three micromass cultures were prepared in each well, using three $5 \mu \mathrm{l}$ drops of the cell suspension. After two hours, chondrogenesis-inducing medium was added to wells and replaced every two to three days. Control cells were submitted to the same protocol, however after two hours the same maintenance media in which they were cultured were added. After 16 days, media were removed from the wells, which were washed with PBS and micromasses were fixated in $4 \%$ formalin for 30 minutes. Following, washing with PBS was performed and Alcian Blue solution (Sigma, Cat. B8438) in 3\% acetic acid was added for 30 minutes for coloration. Then, three washings in wells were performed with $3 \%$ acetic acid and then distilled water was added to neutralize the acidity.

Statistical analysis. Statistical analysis was performed with Wilcoxon rank-sum test for transportation media data, whi- 
ch were expressed as scores and the difference between means was determined by Kruskal-Wallis test. Significance level was set at $\mathrm{p}<0.10$. ANOVA parametric test for inequality of population means, Bartlett's test for inequality of population variances and Mann-Whitney/Wilcoxon two-sample test were applied for multiple comparisons. In order to detect statistical differences in MTT assay, a $\mathrm{p}<0.05$ significance level was considered by Epi Info 7 processing.

\section{RESULTS}

\section{Transport and isolation}

Cells were isolated from Wharton's jelly of ovine umbilical cord at natural birth using an explant culture protocol without enzymatic digestion. All samples presented adhesion to the plastic surface of the culture plates and fibroblastic morphology. For each transport medium, four culture media were tested. Cells initiated migration from

Table 1. Means and total score classification assigned to fibroblastic cell quantities around Wharton's jelly explants from ovine umbilical cords at day four of culture with samples transported in MEM, low glucose DMEM, RPMI 1640, M199, PBS and S

\begin{tabular}{lccccccc}
\hline Transport media & \multicolumn{4}{c}{ Culture media } & & \multicolumn{2}{c}{ Classification } \\
\cline { 2 - 5 } & MEM & DMEM & M199 & RPMI & & & \\
\hline MEM & 8 & 11.5 & 21.5 & 8 & & 49 & 12.2 \\
DMEM & 14 & 19.5 & 21.5 & 23.5 & & $78.5^{*}$ & $19.6^{*}$ \\
RPMI & 11.5 & 16.5 & 23.5 & 16.5 & & 68 & 17.0 \\
M199 & 16.7 & 5 & 19.5 & 5 & & 46.2 & 11.5 \\
PBS & 8 & 16.5 & 1 & 2.5 & & 28 & 7.0 \\
S & 11.5 & 11.5 & 5 & 2.5 & & 30.5 & 7.6 \\
\hline
\end{tabular}

*Statistically different. $(\mathrm{p}<0.10)$.



Fig.1. (A) Morphology of ovine WJUC cells at day 16 of culture in MEM, (B) low glucose DMEM, (C) M199 and (D) RPMI 1640. P0. 100x, Bars: $100 \mu \mathrm{m}$. the edge of the tissue fragments of Wharton's jelly and first fibroblastic cells were observed after four days of culture. Scores of 0-3 were assigned to each treatment (Table 1) and the best results were observed in the wells with explants transported with low glucose DMEM $(p<0.10)$ with an intermediate classification (19.6), followed by RPMI 1640 (17.0), MEM (12.2), M199 (11.5), SF (7.6) and PBS (7.0). Cells obtained from transportation with low glucose DMEM were selected to continue the experiment. After 16 days, single layers cultured in four different media achieved 100\% confluence (Fig.1) and then were transferred to tissue culture flasks.

\section{MTT essay for cell viability}

Culture with MEM provided more viable cells after trypsinization (day 1) with an average optical density of 0.344 , followed by M199 with 0.276, low glucose DMEM with 0.275 and RPMI 1640 with 0.197 (Fig.2). Growth was analyzed every 24 hours, and low glucose DMEM maintained growth, with the lowest decrease in optical density percentage during the four days, followed by RPMI 1640, M199 and MEM (Table 2). Optical density was significantly different $(\mathrm{p}<0.05)$ among media in all days of the experiment.

\section{Adipogenic differentiation}

After 14 days of adipogenic induction, cells isolated in MEM, low glucose DMEM and M199 presented adipogenic differentiation capacity, however cells isolated in RPMI

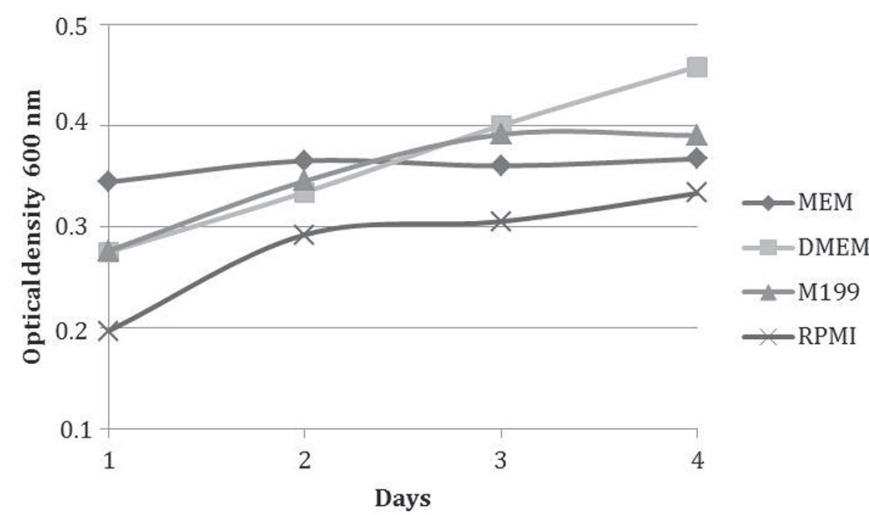

Fig.2. Viability assessment with MTT test of ovine WJUC cells cultured in MEM, low glucose DMEM, M199 and RPMI 1640 during four days.

Table 2. Growth analyzed by absorbance percentage of MTT test results performed in fibroblastic cells from ovine WJUC cells cultured in MEM, low glucose DMEM, M199 and RPMI 1640 during four days

\begin{tabular}{|c|c|c|c|c|c|c|c|c|}
\hline \multirow[t]{2}{*}{ Day } & \multicolumn{2}{|c|}{ MEM } & \multicolumn{2}{|c|}{ Low Glucose DMEM } & \multicolumn{2}{|c|}{ M199 } & \multicolumn{2}{|c|}{ RPMI } \\
\hline & $\begin{array}{c}\text { ABS } \\
\text { means }\end{array}$ & $\begin{array}{c}\text { Growth } \\
\%\end{array}$ & $\begin{array}{c}\mathrm{ABS} \\
\text { means }\end{array}$ & $\begin{array}{c}\text { Growth } \\
\%\end{array}$ & $\begin{array}{c}\text { ABS } \\
\text { means }\end{array}$ & $\begin{array}{c}\text { Growth } \\
\%\end{array}$ & $\begin{array}{c}\text { ABS } \\
\text { means }\end{array}$ & $\begin{array}{c}\text { Growth } \\
\%\end{array}$ \\
\hline 01 & 0.344 & - & 0.275 & & 0.276 & & 0.197 & - \\
\hline 02 & 0.365 & $5.87^{\mathrm{a}}$ & 0.334 & $21.37^{\mathrm{a}}$ & 0.345 & $25.00^{\mathrm{a}}$ & 0.262 & $33.08^{\mathrm{a}}$ \\
\hline 03 & 0.360 & $-1.35^{\mathrm{b}}$ & 0.400 & $19.67^{b}$ & 0.391 & $13.14^{\mathrm{b}}$ & 0.305 & $16.34^{\mathrm{b}}$ \\
\hline 04 & 0.367 & $1.99^{\mathrm{c}}$ & 0.458 & $14.36^{\mathrm{b}}$ & 0.390 & $-0.33^{c}$ & 0.333 & $9.18^{\mathrm{c}}$ \\
\hline
\end{tabular}

$\overline{\mathrm{ABS}}=$ Absorbance. Distinct letters in sequence within columns mark statistical difference. $(\mathrm{p}<0.05)$. 

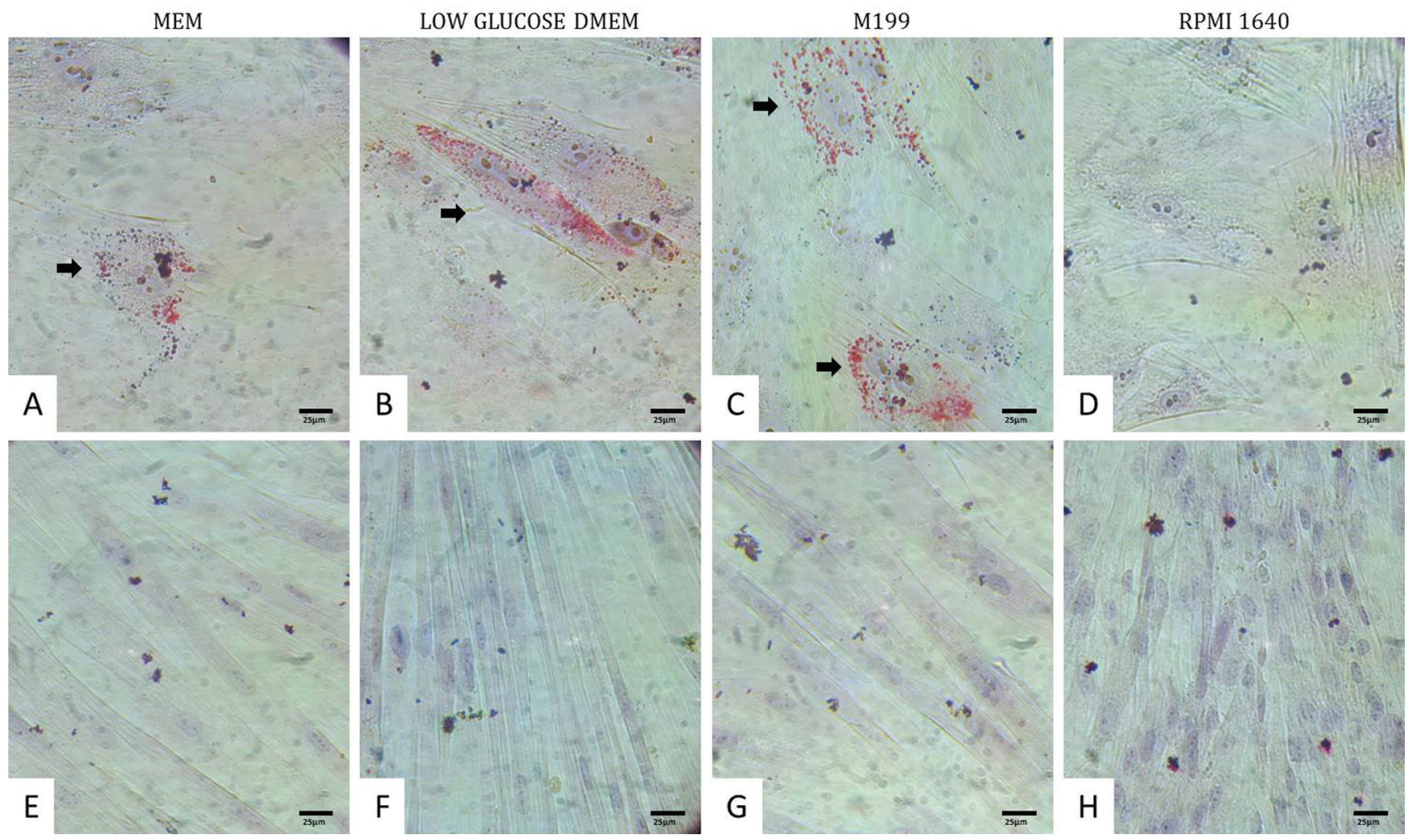

Fig.3. Adipogenic differentiation of ovine WJUC cells confirmed by the visualization of intracytoplasmic lipid drops stained in red (arrows). (A) Isolated cells MEM, (B) low glucose DMEM, (C) M199 and (D) RPMI exposed to adipogenesis-inducing medium. (E) Control wells with ovine WJUC cells not induced to differentiation and cultured in MEM, (F) low glucose DMEM, (G) M199 (G) and (H) RPMI 1640, P2, day 14. Stained with Oil Red 0 and counterstained with hematoxylin. 400x, Bars: $25 \mu \mathrm{m}$.
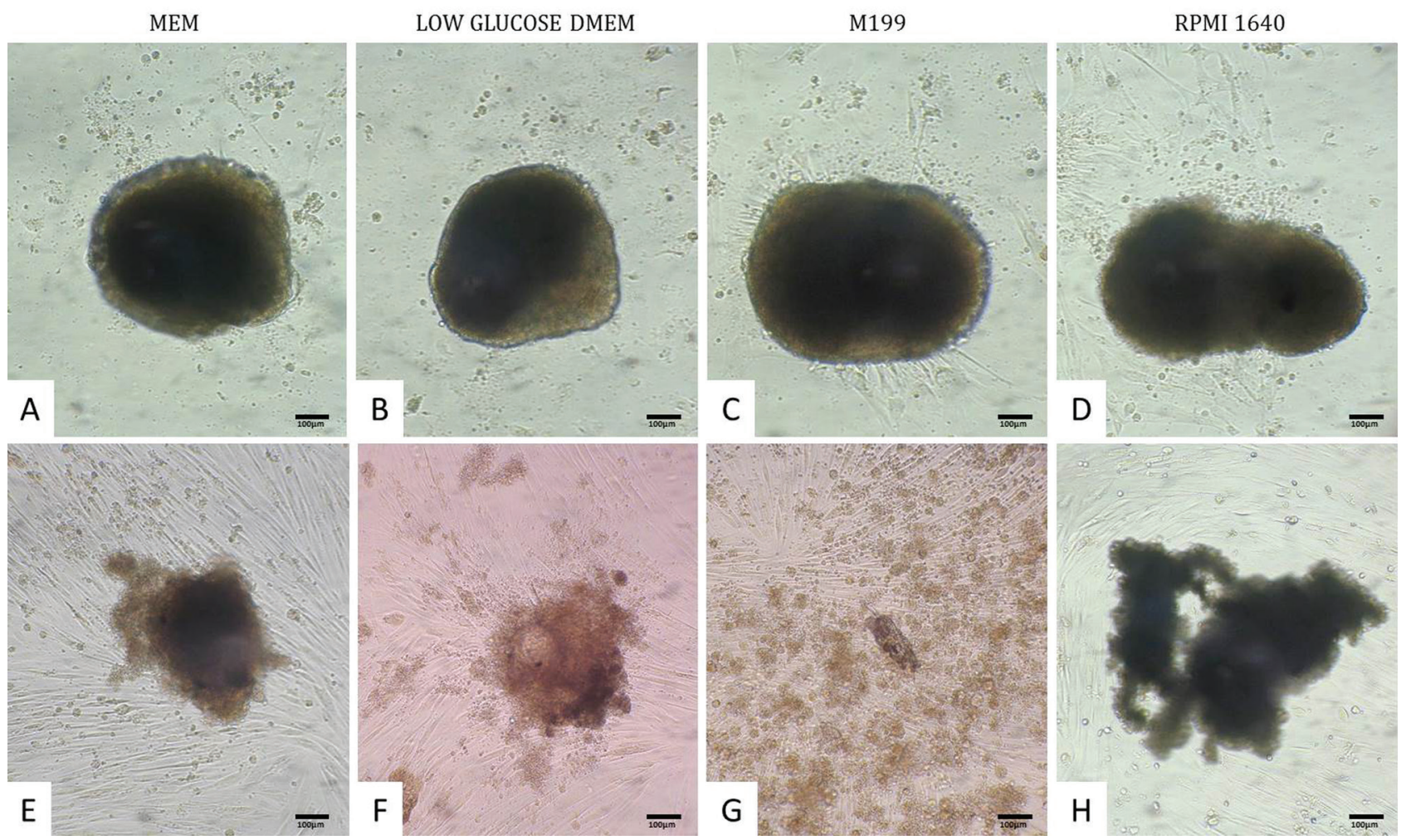

Fig.4. (A) Micromasses of ovine WJUC cells isolated in MEM, (B) low glucose DMEM, (C) M199 and (D) RPMI 1640, and exposed to chondrogenesis-inducing medium.(E) Control wells with micromasses of ovine WJUC cells not induced to differentiation cultured in

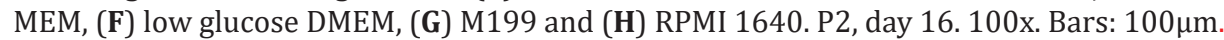



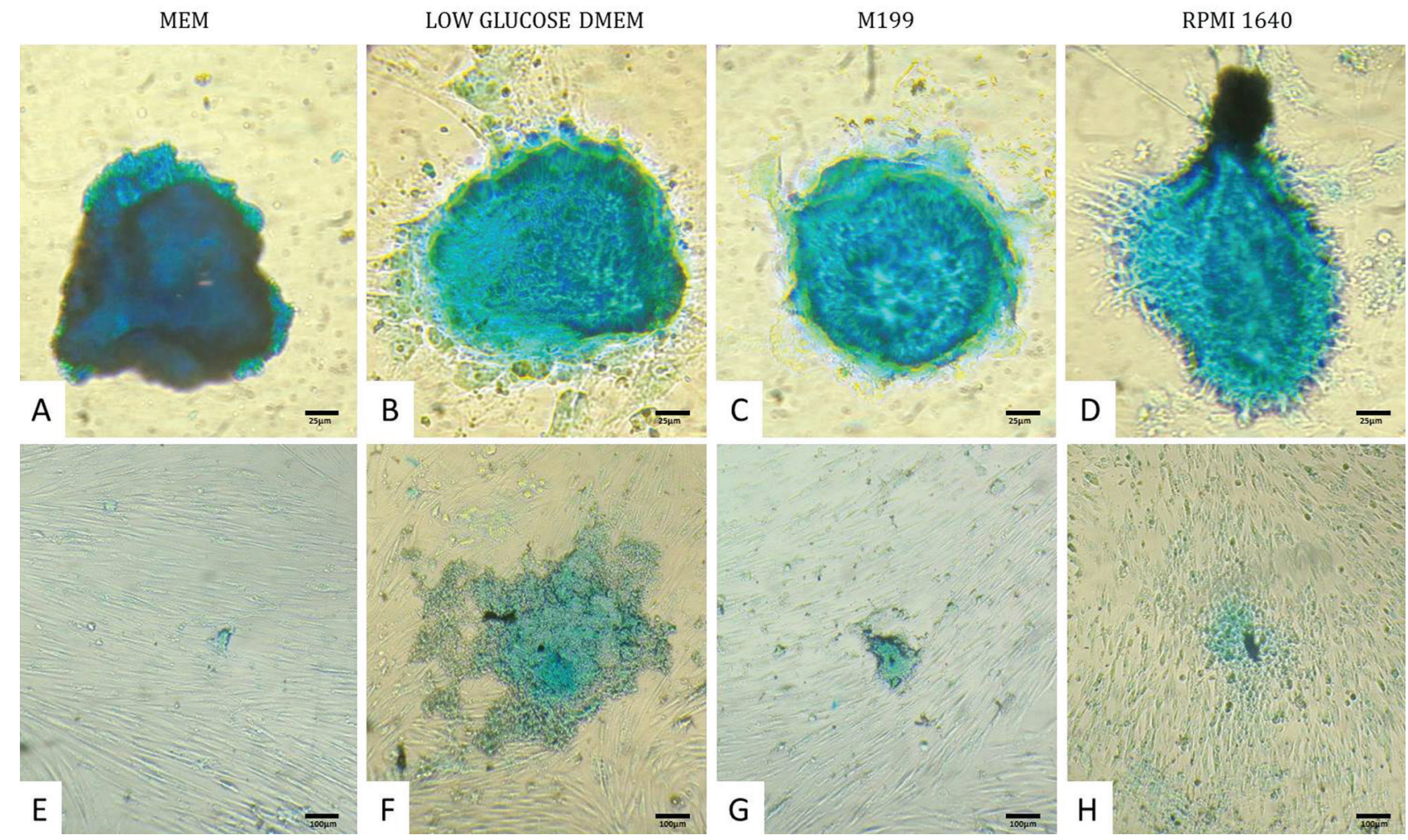

Fig.5. Chondrogenic differentiation of ovine WJUC cells confirmed by the visualization of a blue coloration, which indicates proteoglycan synthesis by chondrocytes. (A) Chondrogenic islands formed by cells isolated in MEM, (B) low glucose DMEM, (C) M199 and (D) RPMI 1640,

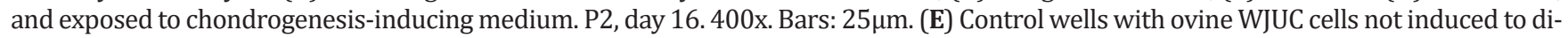
fferentiation and cultured in MEM, (F) low glucose DMEM, (G) M199 and (H) RPMI 1640. P2, day 16. 100x, Alcian Blue stain, Bars: 100 $\mu \mathrm{m}$.
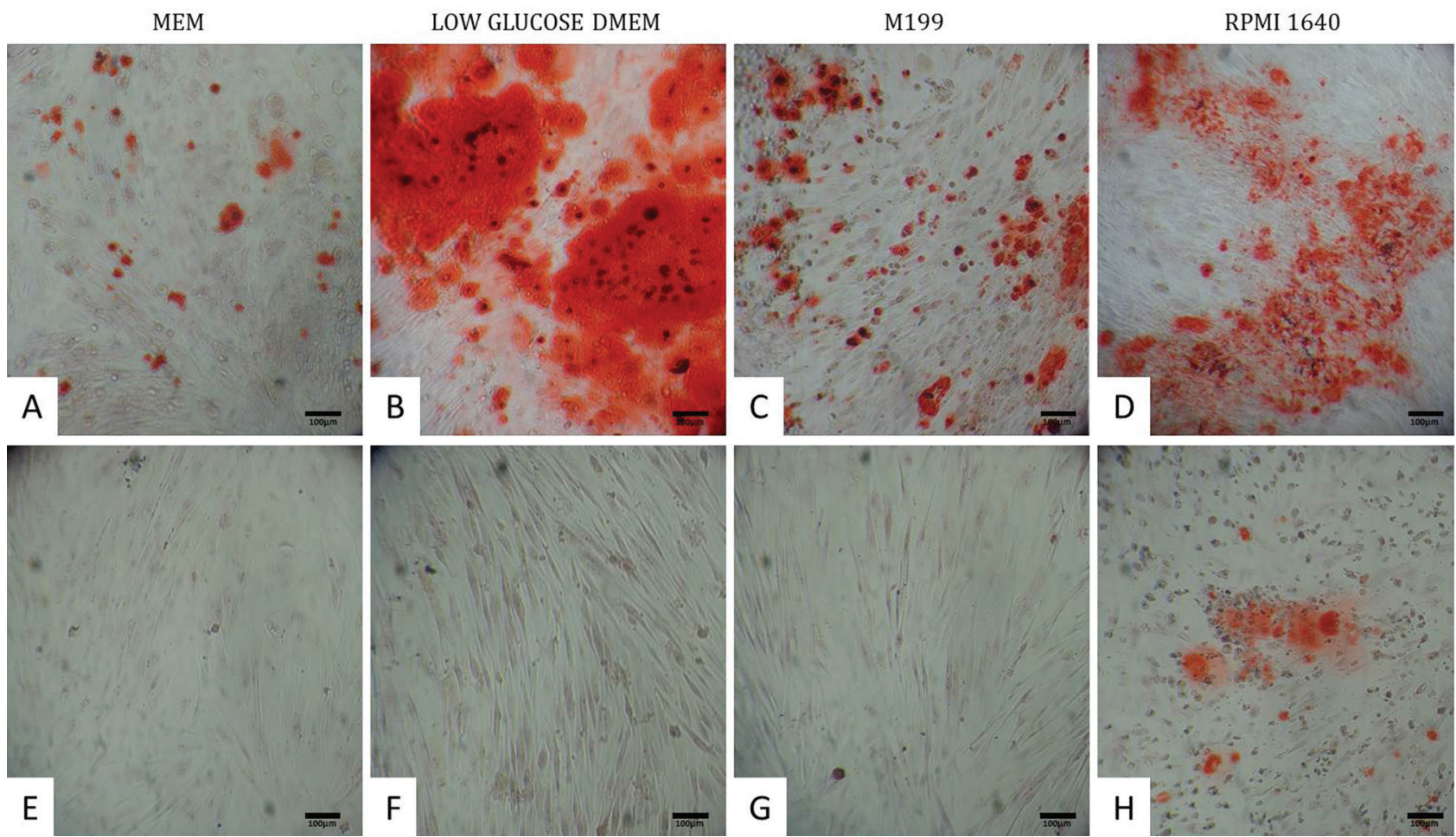

Fig.6. Osteogenic differentiation of ovine WJUC cells confirmed by the red coloration, which indicates extracellular calcium deposits by osteocytes. Cells isolated in (A) MEM, (B) low glucose DMEM, (C) M199 and (D) RPMI 1640, and exposed to osteogenesis-inducing medium. Control wells with ovine WJUC cells not induced to differentiation and cultured in (E) MEM, (F) low glucose DMEM and (G) M199. Control well with ovine WJUC cells presenting a not induced and, therefore, spontaneous differentiation in (H) RPMI 1640 medium. P2, day 21.100x, Alizarin Red S stain, Bars: $100 \mu \mathrm{m}$. 
1640 did not. Differences were observed in the adipogenic differentiation capacity of cells due to the formation of intracytoplasmic lipid drops, which were stained by Oil Red 0 solution. Cells isolated in low glucose DMEM presented the highest concentration of these drops, followed by M199 and MEM isolated cells. All adipogenesis-induced cells presented morphological alterations of polygonal shape (Fig.3A-D) and control group cells remained with fusiform fibroblastic morphology (Fig.3E-G). However, cells from RPMI 1640 control presented an irregular and less stretched morphology (Fig.3H). Adipogenic differentiation did not occur in any of the control wells.

\section{Chondrogenic differentiation}

In 13 hours after the addition of chondrogenesis-inducing medium, drops in cells isolated in low glucose DMEM aggregated into micromasses, followed by MEM isolated cells in 19 hours and M199 along with RPMI 1640 only in 34 hours (Fig.4A-D).

Drops in cells from control wells also agglutinated, however a single layer of fibroblasts grew from them, while micromass cells detached along the experiment (Fig.4E-H). After 16 days of differentiation, Alcian blue coloration was performed directly onto the plates, which allowed the visualization of intense blue coloration indicative of proteoglycan synthesis by chondrocytes in cells isolated and maintained in MEM, low glucose DMEM, M199 and RPMI 1640 (Fig.5A-D). In control wells, the blue color was discreet or absent (Fig.5E-H).

\section{Osteogenic differentiation}

After 21 days of osteogenesis induction, all isolated cells presented the capacity to differentiate (Fig.6A-D), however a superior quantity of extracellular calcium deposition was observed, stained red in cells isolated and maintained with low glucose DMEM, indicating that these cells differentiated into functional osteoblasts in higher proportion. Cells isolated in MEM presented the lowest quantities of calcium deposition among treatments. Cells isolated in RPMI 1640 showed a dispersed calcium deposition in comparison to other groups (Fig.6D). There was no calcium deposition in control groups (Fig.6E-G), except in cells cultured in RPMI 1640, which presented extracellular calcium deposition (Fig.6H).

\section{DISCUSSION}

Multipotent cells have a lot of potential for several cell-dependent therapies and the current isolation techniques provide low quantities of these cells, which may be improved with in vitro expansion. However, the potential to expand is limited by in vitro aging, which leads to a loss of multipotency and replicative senescence. Stress induced by culture conditions is probably one of the main factors that affect these phenomena, which may be reduced through improvement of culture techniques (Stolzing et al. 2006). This study describes collection, isolation and in vitro mesodermal differentiation of cells from ovine Wharton's jelly maintained in different culture media that have different concentrations of amino acids, vitamins, ions and calories.
Caloric restriction is the only method established for slowing down aging and extending cellular lifespan and it has been proven that reducing glucose concentrations lead to an apoptosis reduction and improvement of cellular proliferation (Stolzing et al. 2006). In addition, calcium and phosphate concentrations also influence growth and differentiation, and optimal concentrations for calcium ion of $1.8 \mathrm{mM}$ and for phosphate ion $0.09 \mathrm{mM}$ have been established. Changes in these concentrations may lead to inhibition in growth and/or differentiation capacity in these cells (Liu et al. 2009).

Several culture media have been used in studies with cells from Wharton's jelly of mammalian umbilical cords, among which are $\alpha$-MEM, MSCBM (Passeri et al. 2009), DMEM/TCM199 (Iacono et al. 2012), high glucose DMEM (Hendijani et al. 2014) and DMEM (Sreekumar et al. 2014). The media used in the present study, which are MEM, low glucose DMEM, M199 and RPMI 1640, are usually used due to their capacity of supporting growth of different types of cells. However, there are differences in the compositions of these culture media, which may influence proliferation, viability and in vitro cellular differentiation (Wu et al. 2009).

Choosing an adequate culture medium is an important step for success in cell culture (Wu et al. 2009), therefore, this study aimed to investigate which medium is ideal for in vitro culture of ovine umbilical cord. MEM is the most commonly used medium among others in cellular culture and is considered to have a low concentration of phosphate $(1 \mathrm{mM})$ and glucose $(1 \mathrm{~g} / \mathrm{L})$ and high calcium concentration (1.8mM) (Lopez-Cazaux et al. 2006). Low glucose DMEM is unique among other media due to the elevated amino acid and vitamins concentrations, which are four times higher than MEM, while possessing the same levels of glucose, calcium and phosphate. M199 has the same levels of glucose, calcium and phosphate then MEM and low glucose DMEM; however, it possesses additional exclusive components, which are adenine, adenosine, hypoxanthine, thymine and additional vitamins (Morgan \& Morton 1957). RPMI 1640 medium contains biotin, vitamin B12 and PABA, which are not found in other media, and has nutritional values similar to MEM, but different ionic concentrations. This medium has a low calcium concentration $(0.8 \mathrm{mM})$ and high phosphate concentration $(5 \mathrm{mM})$, however with twice the glucose concentration $(2 \mathrm{~g} / \mathrm{L})$ when compared to MEM, low glucose DMEM and M199 (Lopez-Cazaux et al. 2006).

Iacono et al. (2012) reported problems with bacterial and yeast contamination in the culture of equine Wharton's jelly cells by the microbiota in the birth canal and environmental conditions of collection, even with immersion of umbilical cords for 10 minutes in $70 \%$ alcohol. Passeri et al. (2009) tested three transportation and isolation protocols of equine umbilical cords to avoid fungal and bacterial contaminations, and the best results were obtained with immersion of the umbilical cords overnight in the transport medium containing 5\% $\mathrm{P} / \mathrm{S}$ and $2 \%$ amphotericin $\mathrm{B}$.

In this study, contamination did not occur at collection, since umbilical cords were collected before rupture, using sterile equipment, without contact with soil and were immediately washed with PBS added $2 \% \mathrm{P} / \mathrm{S}$ and immersed 
in transport solutions containing 4\% $\mathrm{P} / \mathrm{S}$ and $1 \%$ amphotericin B.

The long distances between the locations in which animals are housed and the laboratory demand ideal transport conditions. Therefore, the study was performed to assess the effects of transport media in the development of first cells with in vitro culture as a strategy to improve collections, and low glucose DMEM was significantly superior $(\mathrm{p}<0.10)$. Explants from umbilical cords that were transported in low glucose DMEM produced more primary cells after four days of culture when compared to other media used in transportation, which were RPMI 1640, MEM, M199, PBS and S, as shown in Table 1. Sigalas et al. (2004) reported that the culture medium DMEM preserved better the cells from human periodontal ligament stored at room-temperature and in ice for one hour, after which superior viability was observed in 0,24 and 48 hours of culture and these results corroborate with the present study.

The isolation method used in this study was efficient, simple and consistent, producing great quantities of homogeneous fibroblastic cell populations in the four media studied, without visible morphological differences (Fig.1). However, in second passage, morphological differences were observed. Cells cultured in low glucose DMEM presented a narrow and stretched aspect, while cells cultured in MEM and M199 revealed a discreet cytoplasm enlargement close to the nucleus position, and cells isolated in RPMI 1640 presented a disorganized morphology, with a round and irregular conformation when confluent (Fig.3E-H). These findings corroborate with other studies that demonstrated that the number of passages (Maciel et al. 2014) and the culture medium (Fong et al. 2007, Ribeiro et al. 2013) influence the morphology of cells during culture.

No difference in the duration necessary to obtain confluence was observed and in day 16, primary cells (P0) of Wharton's jelly cultured in MEM, low glucose DMEM, M199 and RPMI 1640 achieved $100 \%$ of confluence, when were trypsinized and transferred to culture flasks of $25 \mathrm{~cm}^{2}$.

Metabolic assessment by MTT test demonstrated that cells presented a higher proliferation $(p<0.05)$ when cultured in low glucose DMEM, followed by RPMI 1640, M199 and MEM, due to the minor decrease in growth percentage during culture, maintaining $14.36 \%$ of growth at day four, while MEM, M199 and RPMI 1640 grew 1.99\%, $-0.33 \%$ and $9.18 \%$, respectively at the same day (Table 2). However, culture with medium RPMI 1640 revealed that after trypsinizations, many cells remained in suspension, indicating cellular death, which was confirmed with a minor absorbance in MTT test with 24 hours. In this day, optical density obtained with RPMI 1640 medium was the lowest, with an average of 0.197 when compared to low glucose DMEM, which was 0.275 , while M199 was 0.276 and the higher was MEM with 0.344 , which presented the best support to trypsinization process (Fig. 2 and Table 2).

Multipotent cells tend to decrease their multipotency over culture duration (Liu et al. 2004). Therefore, a differentiation assay with three mesodermal cell lines was performed in low passage (P2) in order to solely verify the effects of culture media on cell isolation and maintenance of multipotency.

In adipogenesis induction, only the cells cultured in RPMI 1640 did not differentiate, not presenting intracytoplasmic lipid drops stained red by Oil Red 0 (Fig.3D). Low glucose DMEM and M199 allowed cells to respond better to this induction, with a discreet but visible superiority when compared to MEM (Fig.3B,C). These data corroborate with the methodology proposed by Carswell et al. (2012), which indicate both DMEM and M199 as the ideal media for isolation and culture of adipocytes. Janderová et al. (2003) report a superior differentiation in human mesenchymal stem cells into adipocytes provided by M199 added with adipogenic factors, when compared to high glucose DMEM. There was no adipogenic differentiation in any of the negative controls.

The best method for in vitro chondrogenic studies is micromass culture (Zhang et al. 2010). Although there are no studies correlating the formation speed of cellular aggregates with a chondrogenic differentiation potential of multipotent cells, in this study there was difference in this behavior specifically concerning time. After 13 hours with the chondrogenesis-inducing medium, cells isolated in low glucose DMEM coalesced forming micromasses, followed by MEM cells, after 19 hours, and M199 and RPMI 1640 cells after 34 hours.

Miura e Shiota (2000) studying micromasses in vitro demonstrated that cells from bone marrow of rat fetuses presented different cellular motility during migration for chondrogenic islands formation, depending if they were cultured in liquid medium or gel (agarose or collagen), reporting the occurrence of chondrogenic islands in 24 hours of culture. In addition, Awad et al. (2000), observed that contraction kinetics vary according to the initial cellular density of the culture, demonstrating a shorter time to the formation of chondrogenic aggregates, when cells are seeded in high density.

Chondrogenic aggregates are a consequence of the separation of chondrogenic cells from a heterogeneous population (Cottrill et al. 1987a). The presence of myofibroblasts may affect in vitro morphogenesis of cartilage and micromass behavior reflects the interactions with a different cell population (Cottrill et al. 1987b). This possible cellular heterogeneity is reinforced by the fact that tissue from Wharton's jelly of umbilical cords have stromal cells that, during pregnancy, acquire specific characteristics of myofibroblasts with the objective of protecting umbilical veins from compressions, but also serving as a niche for mesenchymal stem cells (Kobayashi et al. 1998).

Therefore, different times in which cells coalesce may have resulted from a cellular heterogeneity, in a greater or minor proportion, caused by different culture medium compositions in which the ovine WJUC cells were isolated and maintained. At the end of 16 days, positive intense marking with Alcian blue was observed confirming chondrogenesis in all four treatments (Fig.5A-D).

About osteogenesis, extracellular quantities were clearly different, even if subjectively, among ovine Wharton's jelly cells from ovine cord, showing that culture medium in 
which cells are isolated and maintained affects, maintaining or not, the capacity for in vitro osteogenic differentiation. The visualization in red of the extracellular calcium by alizarin red demonstrated the superiority of low glucose DMEM in the isolation and maintenance of the osteogenic differentiation capacity of ovine WJUC cells.

The data from this study corroborate with the findings of Wu et al. 2009, which reported in canine periosteum cells the superiority of low glucose DMEM for cellular differentiation when compared to RPMI 1640. In addition, these authors reported that mineralized nodules from culture with RPMI 1640 were distributed in a more dispersed pattern. This behavior was also demonstrated in this study, in which extracellular calcium deposition occurred in a less concentrated and more dispersed manner on the single layer of cells isolated in this medium (Fig.6D).

Osteogenic differentiation in cells isolated and maintained with M199 presented inferior quantities of extracellular calcium deposition when compared to DMEM and RPMI, followed by MEM maintained cells, which demonstrated the least effective capacity of osteoblast differentiation among the four tested media (Fig.6A-D). These findings disagree with the results from Lopez-Cazaux et al. (2006), who reported the superiority of MEM in comparison with RPMI in proliferation and differentiation into odontoblast-like cells from human dental pulp. Possibly, cells from different origins have distinct nutritional requirements, which reflect in a behavioral variation when using the same culture medium.

In the control group negative for osteogenic differentiation, extracellular calcium deposition did not occur, except in cells cultured in RPMI, which presented positive red markings (Fig.6H), however these cells were not exposed to the osteogenesis-inducing medium. Spontaneous mineralization in vitro and without induction with $\beta$-glycerophosphate or dexamethasone have been reported in cellular culture of human dental pulp (Alliot-Licht et al. 2001) and canine periosteum (Wu et al. 2009), both cultured in RPMI 1640 medium. The hypothesis created by one of the authors for this phenomenon is the presence of pericytes or myofibroblasts that incorporate calcium phosphate from nodule formation that appear when cells remain in a long period at $100 \%$ of confluence. Also, spontaneous mineralization is cell-density dependent and our study demonstrated that culture medium is an important factor as well, since there was no calcium deposition in the control group of other treatments.

Low glucose DMEM is a medium with caloric restriction, only $1 \mathrm{~g} / \mathrm{L}$ of glucose, and ideal concentrations of phosphate and calcium for multipotent cells culture, however it is also unique for possessing four times the quantity of amino acids and vitamins. When compared to MEM and M199, which has the same glucose, phosphate and calcium concentrations, low glucose DMEM was superior in this study, demonstrating the positive effect caused by the superior concentration of amino acids and vitamins in maintaining cellular multipotency. RPMI 1640 induced a spontaneous osteogenic differentiation, which probably hindered the adipogenic differentiation in cells isolated in this medium, and therefore does not preserve multipotency of cells from ovine Wharton's jelly.

Based on our findings, cells from Wharton's jelly of ovine umbilical cord present different potentials for in vitro differentiation depending on the culture medium used in isolation and maintenance. Low glucose DMEM was the most adequate medium for culture, providing the most intense cellular proliferation and best results in adipogenic, chondrogenic and osteogenic in vitro differentiations.

\section{CONCLUSIONS}

Cells from Wharton's jelly of ovine umbilical cords collected at natural birth possess fibroblastic morphology and the capacity for in vitro differentiation into adipogenic, chondrogenic and osteogenic cell lines.

Cellular culture medium modulates behavior of these cells and is a major factor for proliferation and maintenance of multipotency, for which low glucose DMEM is the most adequate for transportation and culture of cells from Wharton's jelly of ovine umbilical cords.

Acknowledgments- The authors would like to thank CNPq (Universal proc. 487425/2012-0) and AUXPE-PROEX 533/2014 for the financial support, and to CAPES for granting the doctoral scholarship.

Conflict of interest statement.- The authors have no competing interests.

\section{REFERENCES}

Alliot-Licht B., Hurtrel D. \& Gregoire M. 2001. Characterization of a-smooth muscle actin positive cells in mineralized human dental pulp cultures. Arch. Oral Biol. 46:221-228.

Awad H.A., Butler D.L., Harris M.T., Ibrahim R.E., Wu Y., Young R.G., Kadiyala S. \& Boivin G.P. 2000. In vitro characterization of mesenchymal stem cell-seeded collagen scaffolds for tendon repair: effects of initial seeding density on contraction kinetics. J. Biomed. Mater Res. 51:233-240.

Azari O., Babaei H., Derakhshanfar A., Nematollahi-Mahani S.N., Poursahebi R. \& Moshrefi M. 2011. Effects of transplanted mesenchymal stem cells isolated from Wharton's jelly of caprine umbilical cord on cutaneous wound healing; histopathological evaluation. Vet. Res. Commun. 35(4):211-22.

Baksh D., Yao R. \& Tuan R.S. 2007. Comparison of proliferative and multilineage differentiation potential of human mesenchymal stem cells derived from umbilical cord and bone marrow. Stem Cells 25(6):13841392.

Baksh D., Song L. \& Tuan R.S. 2004. Adult mesenchymal stem cells: characterization, differentiation, and application in cell and gene therapy. J. Cell Mol. Med. 8(03):301-316.

Carswell K.A., Lee M. \& Fried S.K. 2012. Culture of isolated human adipocytes and isolated adipose tissue. Methods Mol. Biol. 806:203-214.

Colosimo A., Russo V., Mauro A., Curini V., Marchisio M., Bernabò N., Alfonsi M., Mattioli M. \& Barboni B. 2013. Prolonged in vitro expansion partially affects phenotypic features and osteogenic potential of ovine amniotic fluid-derived mesenchymal stromal cells. Cytotherapy 15(8):930-950.

Condic M.L. \& Rao M. 2010. Alternative sources of pluripotent stem cells: Ethical and scientific issues revisited. Stem Cells Dev. 19(8):1121-1129.

Cottrill C.P., Archer C.W., Hornbruch A. \& Wolpert L. 1987a. The differentiation of normal and muscle-free distal chick limb bud mesenchyme in micromass culture. Dev. Biol. 119:143-156.

Cottrill C.P., Archer C.W. \& Wolpert L. 1987b. Cell sorting and chondrogenic aggregate formation in micromass culture. Dev. Biol. 122:503-515.

De Vita B., Campos L.L., Listoni A.J., Maia L., Freitas N.P.P., Alvarenga F.L. \& Prestes N.C. 2012. Anexos fetais: Uma fonte alternativa de células- 
tronco mesenquimais para a medicina veterinária equina. Vet. Zootec. 19(1):8-22.

Fadel L., Viana B.R., Feitosa M.L., Ercolin A.C., Roballo K.C., Casals J.B., Pieri N.C., Meirelles F.V., Martins D.S., Miglino M.A. \& Ambrosio C.E. 2011. Protocols for obtainment and isolation of two mesenchymal stem cell sources in sheep. Acta Cir. Bras. 26:267-273.

Fauza D.O., Jennings R.W., Teng Y.D. \& Snyder E.Y. 2008. Neural stem cell delivery to the spinal cord in an ovine model of fetal surgery for spina bifida. Surgery 144:367-373.

Fong C.Y., Richards M., Manasi N., Biswas A. \& Bongso A. 2007. Comparative growth behaviour and characterization of stem cells from human Wharton's jelly. Reprod. BioMed. Online 15(6):708-718.

Forraz N. \& McGguckin C.P. 2010. The umbilical cord: a rich and ethical stem cell source to advance regenerative medicine. Cell Prolif. 44(1):60-69.

Guo X., Wang C., Duan C., Descamps M., Zhao Q., Dong L., Lu S., Anselme K., Lu J. \& Song Y.Q. 2004. Repair of osteochondral defects with autologous chondrocytes seeded onto bioceramic scaffold in sheep. Tissue Eng. 10:1830-1840

Gronthos S., Mrozik K., Shi S. \& Bartold P.M. 2006. Ovine periodontal ligament stem cells: Isolation, characterization, and differentiation potential. Calcif. Tissue Int. 79:310-317

Hendijani F., Sadeghi-Aliabadi H. \& Javanmard S.H. 2014. Comparison of human mesenchymal stem cells isolated by explant culture method from entire umbilical cord and Wharton's jelly matrix. Cell Tissue Bank 15:555-565.

Iacono E., Brunori L., Pirrone A., Pagliaro P.P., Ricci F., Tazzari P.L. \& Merlo B. 2012. Isolation, characterization and differentiation of mesenchymal stem cells from amniotic fluid, umbilical cord blood and Wharton's jelly in the horse. Reproduction 143:455-468.

Iacono E., Rossi B. \& Merlo B. 2015. Stem cells from foetal adnexa and fluid in domestic animals: An update on their features and clinical application. Reprod. Dom. Anim. 50:353-364

Jahroomishirazi R., Bader A., Ebert S., Schmidt C., Sedaghati B., Schulz-Siegmund M. \& Zscharnack M. 2015. Isolation and characterization of cd $271^{+}$stem cells derived from sheep dermal skin. Cells Tissues Organs 200(2):141-152.

Janderová L., McNeil M., Murrell A.N., Mynatt R.L. \& Smith S.R. 2003. Human mesenchymal stem cells as an in vitro model for human adipogenesis. Obes Res. 11:65-74.

Kobayashi K., Kubota T. \& Aso T. 1998. Study on myofibroblast differentiation in the stromal cells of Wharton's jelly Expression and localization of a-smooth muscle actin. Early Human Develop. 51:223-233.

Lima S.A.F., Wodewotzky T., Lima-Neto J.F., Beltrão-Braga P.C.B. \& Alvarenga F.C.L. 2012. Diferenciação in vitro de células-tronco mesenquimais da medula óssea de cães em precursores osteogênicos. Pesq. Vet. Bras. 32(5):463-469.

Liu L., DiGirolamo C.M., Navarro P.A.A.S., Blasco M.A. \& Keefea D.L. 2004. Telomerase deficiency impairs differentiation of mesenchymal stem cells. Exp. Cell Res. 294(1):1-8.

Liu Y.K., Lu Q.Z., Pei R., Ji H.J., Zhou G.S., Zhao X.L., Tang R.K. \& Zhang M. 2009. The effect of extracellular calcium and inorganic phosphate on the growth and osteogenic differentiation of mesenchymal stem cells in vitro: implication for bone tissue engineering. Biomed. Mater. 4:1-8.

Lopez-Cazaux S., Bluteau G., Magne D., Lieubeau B., Guicheux J. \& Alliot-Licht B. 2006. Culture medium modulates the behaviour of human dental pulp derived cells: technical note. Euro. Cells and Mater. 11:3542 .
Lyahyai J., Mediano D.R., Ranera B., Sanz A., Remacha A.R., Bolea R., Zaragoza P., Rodellar C. \& Martín-Burriel I. 2012. Isolation and characterization of ovine mesenchymal stem cells derived from peripheral blood. BMC Vet. Res. 8:169.

Maciel B.B., Rebelatto C.L.K., Brofman P.R.S., Brito H.F.V., Patricio L.F.L., Cruz M.A. \& Locatelli-Dittrich R. 2014. Morphology and morphometry of feline bone marrow-derived mesenchymal stem cells in culture. Pesq. Vet. Bras. 34(11):1127-1134.

Miura T. \& Shiota K. 2000. Extracellular matrix environment influences chondrogenic pattern formation in limb bud micromass culture: Experimental verification of theoretical models. Anat. Rec. 258:100-107.

McCarty R.C., Gronthos S., Zannettino A.C., Foster B.K. \& Xian C.J. 2009. characterisation and developmental potential of ovine bone marrow derived mesenchymal stem cells. J. Cell. Physiol. 219: 324-333.

Morgan J.F. \& Morton H.J. 1957. The nutrition of animal tissues cultivated in vitro. J. Biophysic. Biochem. Cytol. 3(2):141-150.

Murphy S.V. \& Atala A. 2013. Amniotic fluid and placental membranes: unexpected sources of highly multipotent cells. Semin. Reprod. Med. 31(1):62-68.

Passeri S., Nocchi F., Lamanna R., Lapi S., Miragliotta V., Giannessi E., Abramo F., Stornelli M.R., Matarazzo M., Plenteda D., Urciuoli P., Scatena F. \& Coli A. 2009. Isolation and expansion of equine umbilical cord-derived matrix cells (EUCMCs). Cell Biol. Int. 33:100-105.

Pratheesh M.D., Gade N.E., Dubey P.K., Nath A., Sivanarayanan T.B., Madhu D.N., Sharma B., Amarpal A., Saikumar G. \& Sharma G.T. 2014. Molecular characterization and xenogenic application of Wharton's jelly derived caprine mesenchymal stem cells. Vet. Res. Commun. 38:139-148.

Psaltis P.J., Carbone A., Nelson A.J., Lau D.H., Jantzen T., Manavis J., Williams K., Itescu S., Sanders P., Gronthos S., Zannettino A.C. \& Worthley S.G. 2010. Reparative effects of allogeneic mesenchymal precursor cells delivered transendocardially in experimental nonischemic cardiomyopathy. JACC Cardiovasc. Interv. 3:974-983.

Ribeiro G., Massoco C.O. \& Lacerda Neto J.C. 2013. Culture of equine bone marrow mononuclear fraction and adipose tissue-derived stromal vascular fraction cells in different media. Pesq. Vet. Bras. 33(1):20-24.

Scheerlinck J.P., Snibson K.J., Bowles V.M. \& Sutton P. 2008. Biomedical applications of sheep models: from asthma to vaccines. Trends Biotechnol. 26:259-266.

Sigalas E., Regan J.D., Kramer P.R., Witherspoon D.E. \& Opperman L.A. 2004. Survival of human periodontal ligament cells in media proposed for transport od avulsed teeth. Dent. Traumatol. 20:21-28.

Sill B., Roy N., Hammer P.E., Triedman J.K., Sigg D.C., Kelly M.F., Nedder A., Dunning P.S. \& Cowan D.B. 2011. Development of an ovine model of pediatric complete heart block. J. Surg. Res. 166:103-108.

Sreekumar T.R., Ansari M.M., Chandra V. \& Sharma G.T. 2014. Isolation and characterization of buffalo Wharton's jelly derived mesenchymal stem cells. J. Stem Cell Res. 4:207.

Stolzing A., Coleman N. \& Scutt A. 2006. Glucose-induced replicative senescence in mesenchymal stem cells. Rejuv. Res. 9(1):31-35.

Taghizadeh R.R., Cetrulo K.J. \& Cetrulo C.L. 2011. Wharton's Jelly stem cells: Future clinical applications. Placenta 32:311-315.

Wu X., Lin M., Li Y., Zhao X. \& Yan F. 2009. Effects of DMEM and RPMI 1640 on the biological behavior of dog periosteum-derived cells. Cytotechnology 59:103-111.

Zhang L., Su P., Xu C., Yang J., Yu W. \& Huang D. 2010. Chondrogenic differentiation of human mesenchymal stem cells: a comparison between micromass and pellet culture systems. Biotechnol. Lett. 32:1339-1346. 